\title{
Effects of age and hypophysectomy on responsiveness of rat Leydig cells to $\mathrm{hCG}$
}

\author{
K. Purvis, O. P. F. Clausen* and V. Hansson \\ Institute of Pathology and ${ }^{*}$ Institute of Forensic Medicine, Rikshospitalet, Oslo, Norway
}

\begin{abstract}
Summary. The response of rat Leydig cells to hCG in vitro was examined using decapsulated testes and enriched Leydig cell suspensions of a known purity. The

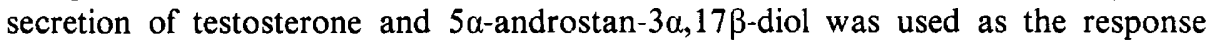
and medium extracts were assayed before and after celite chromatography. At least 4 important phases in the development of steroidogenic function of the Leydig cells were detected. (1) A period after birth up to 10 days of age when the Leydig cell preferentially secretes testosterone. The cells may constitute the remnants of a fetal Leydig cell population. (2) A period which begins between 10 and 15 days of age and continues until 35-40 days of age, when the major products of the Leydig cell are $5 \alpha$-reduced metabolites of testosterone, especially $5 \alpha$-androstan-3 $\alpha, 17 \beta$-diol. (3) A phase at 20-30 days of age when responsiveness of the Leydig cell to hCG in vitro undergoes a distinct increase (the quantity of androgen produced with maximum hCG stimulation) and attains adult levels, although the sensitivity of the Leydig cells to $\mathrm{hCG}$ (the dose of $\mathrm{hCG}$ eliciting a half-maximal response, $\mathrm{ED}_{50}$ ) is gradually decreased after Day 20. (4) A period from 35-40 days of age into adulthood when testosterone increasingly becomes the major secretory product of the Leydig cell.

Hypophysectomy for 8 days decreased the quantity of androgens produced per $10^{6}$ Leydig cells in response to hCG to an extent dependent on age. At 28 days of age steroidogenic function was impaired to a much greater extent (reduced by some $80-90 \%$ ) than at 38 or 58 days (reduced by $40-50 \%$ ). At all ages the sensitivity of the Leydig cells to hCG was increased after hypophysectomy.
\end{abstract}

\section{Introduction}

In the rat the responsiveness of the Leydig cells to $\mathrm{LH} / \mathrm{hCG}$ changes throughout its development. Earlier workers (e.g. Odell, Swerdloff, Bain, Wollesen \& Grover, 1974; Payne, Kelch, Murono \& Kerlan, 1977) evaluated responsiveness with reference to testosterone secretion and ignored the fact that the pattern of steroids secreted by rat Leydig cells changes markedly during the prepubertal period. Before 40-50 days of age, testosterone is a relatively poor indicator of Leydig cell responsiveness because the major secretory products of the Leydig cell before this age are the $5 \alpha$-reduced forms of testosterone (Nayfeh, Barefoot \& Baggett, 1966; Coffey, French \& Nayfeh, 1971; Ficher \& Steinberger, 1971; Matsumoto \& Yamada, 1973). Moreover, little attention was paid to the fact that the size of the Leydig cell population was also changing (Knorr, Vanha-Perttula \& Lipsett, 1970; Pahnke, Leidenberger \& Kunzig, 1975), and this made it difficult to distinguish between effects due to cell recruitment and changes in steroidogenic capacity on a per cell basis. When a more general steroid response was used, involving the measurement not only of testosterone but also of the $5 \alpha$-reduced products of testosterone, $5 \alpha$-androstan-3 $\alpha, 17 \beta$-diol and dihydrotestosterone, and when responses were 
expressed per $10^{6}$ Leydig cells, a different picture emerged (Purvis, Clausen \& Hansson, 1978b). The magnitude of the in-vitro response under conditions of maximum stimulation with hCG were found to have been grossly underestimated during the prepubertal period; in fact, the response was maximum on Day 30 and then appeared to be attenuated as the animal approached puberty. Such findings cast doubt on the early suggestions that puberty in the male rat was associated with an increased responsiveness of the Leydig cells to $\mathrm{LH}$, enabling them to secrete greater quantities of testosterone. A distinction between alterations in sensitivity of the response $\left(\mathrm{ED}_{50}\right)$ to $\mathrm{LH} / \mathrm{hCG}$ and changes in the magnitude of the maximal response can only be accomplished by assessing the responses to multiple doses of hCG. The aims of the present study were (1) to extend our previous observations by examining age-dependent changes in the characteristics of the steroid-response curves after hCG stimulation of rat Leydig cells so that both the sensitivity and the steroidogenic maximum could be better defined, (2) to examine the responsiveness of the testes during the perinatal period to ascertain how early in the development of the testis the Leydig cells have the potential for responding to LH/hCG, and (3) to determine the effects of hypophysectomy at different ages on the dose-response characteristics.

The importance of these studies, in helping to define when Leydig cells acquire the normal capacity for responding to $\mathrm{LH}$, is that they enable one to correlate such changes with fluctuations in endogenous plasma hormones and to evaluate which hormones, if any at all, are normally responsible for conferring this function on Leydig cells during development.

\section{Materials and Methods}

\section{Experiments}

Study 1. Sprague-Dawley male rats were hypophysectomized at 28,38 and 58 days of age. After 8 days they were killed and enriched Leydig cell suspensions were prepared from the testes. Control suspensions were obtained from rats which were at 28,38 and 58 days of age and from rats of the same chronological age as the treatment groups at death (36, 46 and 66 days). A group of 20-day-old rats was also included for comparison. The number of rats in each group varied from 5 to 7 (in immature hypophysectomized and 20-day-old intact rats). The suspensions were prepared using techniques previously described (Purvis, Clausen, Brandtzaeg \& Hansson, 1978a; Purvis et al., 1978b) with two modifications. All steps were performed in medium 199 (Flow Laboratories) and the incubation of the testes with collagenase was carried out in the presence of $0.1 \%$ bovine serum albumin (BSA) to neutralize non-specific proteolytic activity in the enzyme preparation. Cells were exposed to various concentrations of hCG (0-5.0 $\mathrm{ng} / 300 \mu \mathrm{l})$ for $3 \mathrm{~h}$. The purity of each suspension was assessed by counting nucleated cells and

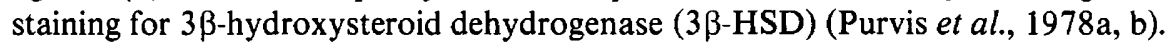

Study 2. Testes from Sprague-Dawley rats of 2, 3, 5, 10 and 15 days of age were decapsulated and placed in glass vials containing medium $199(1 \mathrm{ml})$. For 2-, 3-, and 5-day-old rats, one testis was removed from each of 6 rats of the same age and pooled in one incubation vial. A second pool was prepared from the remaining testes. To one of the pools at each age was added a dose of hCG $(10 \mathrm{ng} / \mathrm{ml})$ which was in excess of that required for maximum stimulation. To the other, which provided information on basal secretion, was added the same volume of saline $(9 \mathrm{~g} \mathrm{NaCl} / \mathrm{l})$. For the 10- and 15-day-old rats (5/group), there were 2 testes in 2 pools and 3 testes in the other 2 pools: one of each pool was the control whilst the other was exposed to hCG $(10 \mathrm{ng} / \mathrm{ml})$. The testes were incubated for $4 \mathrm{~h}$ in a shaking incubator at $34^{\circ} \mathrm{C}$ in an atmosphere of $95 \% \mathrm{O}_{2}: 5 \% \mathrm{CO}_{2}$. After incubation, the media were centrifuged to remove cellular debris and stored at $-20^{\circ} \mathrm{C}$ until the day of assay.

Study 3. Sprague-Dawley rats were killed daily between 21 and 27 days of age (4 rats/group). Testes were decapsulated into individual incubation vials containing medium 199 $(1 \mathrm{ml})$. One of each pair was exposed to hCG $(10 \mathrm{ng} / \mathrm{ml})$ whilst the other acted as control. The testes were then incubated for $4 \mathrm{~h}$ as described for Study 2 . 


\section{Androgen measurements}

In Study 1, the incubation media were assayed for testosterone and 17 $\beta$-hydroxyandrogen using techniques which have already been described (Purvis et al., 1978a, b). The specificity of

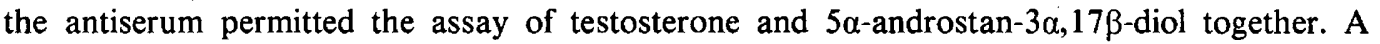
more accurate measurement of the quantity of these two steroids in the extracts was also performed on selected samples by using the same radioimmunoassay procedures but after separation of the steroid constituents by celite chromatography. Details of this technique, including information on specificity and validation, can be obtained elsewhere (Purvis et al., 1978b). The selected samples were those containing no hCG (i.e. basal secretion) and those containing a dose of hCG which had elicited a maximal response $(5 \mathrm{ng} / 300 \mu \mathrm{l})$. In all cases, steroid secretion was expressed per $10^{6} 3 \beta$-HSD positive cells. All samples from Studies 2 and 3 were chromatographed before assay so that an accurate assessment of the $5 \alpha$-androstan$3 \alpha, 17 \beta$-diol :testosterone ratio could be obtained. One important aspect of these studies was to

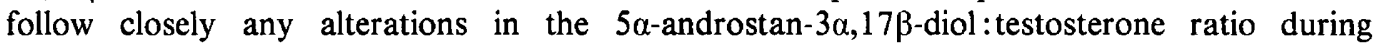
development. To facilitate this, data from all 3 studies were pooled. For completeness, information from 3 additional groups of rats (40,60 and 80 days of age) was also included. For these studies also, enriched Leydig cell suspensions were exposed to saline or a maximum dose of hCG $(5 \mathrm{ng} / 300 \mu \mathrm{l})$ and the $5 \alpha$-androstan-3 $\alpha, 17 \beta$-diol :testosterone ratios were determined after chromatography of the organic extracts.

\section{Results}

\section{Effects of age on characteristics of the steroid-response curves to various doses of $h C G$}

When testosterone was used as the steroid response indicator, there was an apparent increase in the maximum quantity of steroid produced by the Leydig cell between 20 and 66 days of age, with the most significant increase occurring between 38 and 46 days (Text-fig. 1a). Associated with this apparent increase in steroidogenic potential was an elevation in basal secretion. In general the sensitivity of the response decreased with increasing age (Table 1). A different pattern emerged when the secretion of $17 \beta$-hydroxyandrogen was used as the response (Text-fig. 1b). The major change in steroid secretion occurred at 20-28 days and Leydig cells from 28-46-day-old rats exhibited a steroidogenic potential which appeared to be higher than that of the adult Leydig cells (58-66 days). Increasing age was again associated with increased basal secretion (Text-fig. 1b) and a decreasing sensitivity of the dose-response curves (Table 1).

Table 1. Sensitivity of rat Leydig cells to hCG at different stages of development and after 8 days of hypophysectomy (in parentheses) in terms of the dose of hCG required to elicit a half maximal response

$\left(\mathrm{ED}_{\mathrm{s0}}\right)$

\begin{tabular}{ccc}
\hline Age (days) & Testosterone & 17ß-Hydroxyandrogen* \\
\hline 20 & 20 & 25 \\
28 & $80(6)$ & $100(7)$ \\
36 & 95 & 90 \\
38 & $86(16)$ & $110(22)$ \\
46 & 115 & 115 \\
58 & $110(60)$ & $120(55)$ \\
66 & 105 & 150 \\
\hline
\end{tabular}

* Testosterone $+5 \alpha$-androstan-3 $3,17 \beta$-diol. 


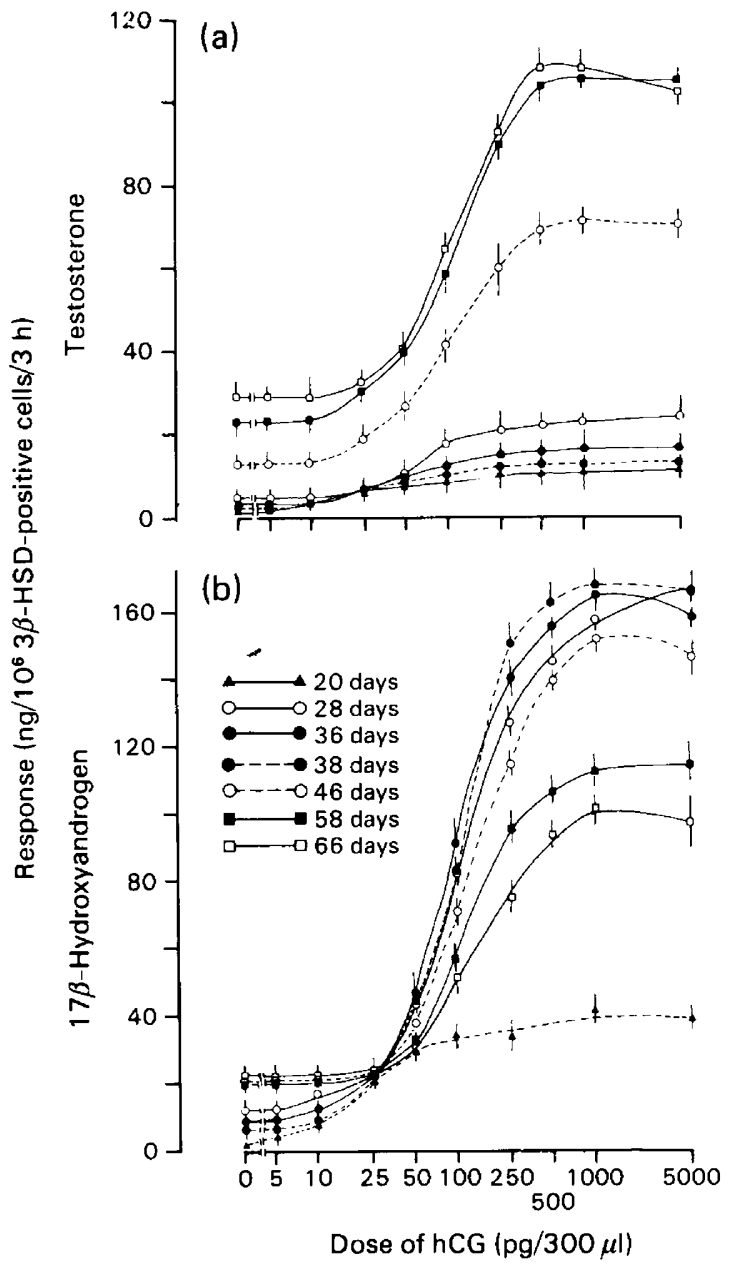

Text-fig. 1. Dose-response (a, testosterone; b, 17 -hydroxyandrogen) curves of enriched rat Leydig cell suspensions after exposure to hCG in vitro. The suspensions were prepared from rats of different ages (5-7/group). Vertical bars represent standard deviations of triplicate incubations.

Effects of hypophysectomy at different ages on the hCG dose-response of isolated Leydig cells

The steroid responses to different doses of hCG are shown in Text-fig. 2. By comparing these data to those depicted in Text-fig. 1, it is obvious that the sensitivity of the Leydig cell to hCG increases (the $\mathrm{ED}_{30}$ is lower) after hypophysectomy, but to an extent dependent on age (Table 1). The most marked alteration in sensitivity occurred in rats hypophysectomized at 28 days of age. The quantity of androgen produced by Leydig cells under conditions of maximum stimulation with hCG was also affected by hypophysectomy to an extent dependent on age: adult rats were relatively more resistant to the effects of the operation than were immature animals (Table 2). Animals hypophysectomized at Day 58 secreted $60-70 \%$ of the testosterone (about $65 \mathrm{ng} / 10^{6}$ Leydig cells) secreted by the intact controls (about $100 \mathrm{ng} / 10^{6}$ Leydig cells; see Text-fig. 1a). The corresponding values for rats hypophysectomized on Days 28 or 38 were $12 \%$ and $50 \%$ when compared on the basis of $17 \beta$-hydroxyandrogen secretion. 


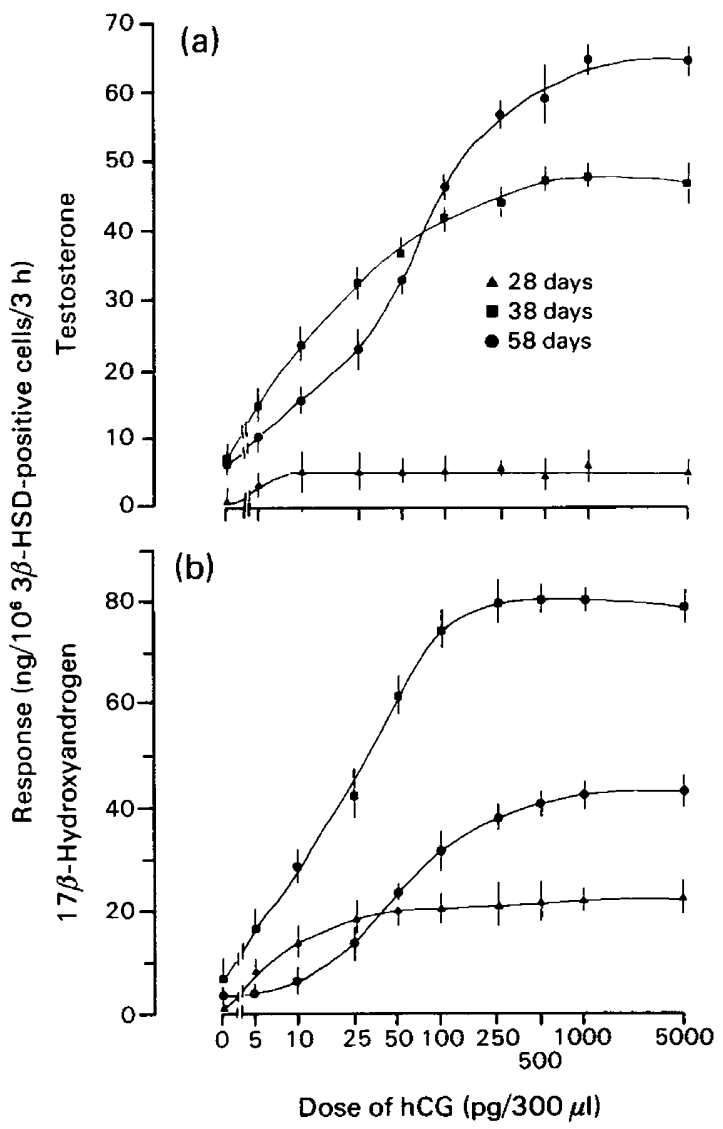

Text-fig. 2. Effects of hypophysectomy for 8 days at different ages on the dose-response (a, testosterone; $b, 17 \beta$-hydroxyandrogen) characteristics of rat Leydig cells to hCG. The vertical bars represent standard deviations of triplicate incubations and there were 5-7 rats/group.

Effects of age and hypophysectomy on the amounts of testosterone and 5a-androstan3a,17ß-diol secreted by isolated Leydig cells

Table 2 summarizes the effects of age and hypophysectomy on androgen secretion by the Leydig cells after maximum stimulation with hCG. The total quantity of androgen (testosterone $+5 \alpha$-androstan-3 $\alpha, 17 \beta$-diol) secreted by the Leydig cells markedly increased after Day 20 but changed relatively little after Day 28 . However, the relative proportion of these two components changed considerably during development. At Day 28 testosterone was a relatively minor secretory product but subsequently became quantitatively more important, especially after Day 38. Hypophysectomy for 8 days caused a major decrease $(80-90 \%)$ in the total quantity of androgen secreted by 28-day Leydig cells but a smaller change in secretion from adult cells. The proportion of testosterone secreted relative to $5 \alpha$-androstan-3a,17 $\beta$-diol increased from about 3.5 to $31 \%$ after hypophysectomy at 28 days of age (Table 2), but there was no comparable alteration in adult rats.

\section{Perinatal changes in testicular responsiveness}

At as early as 2 days of age, the Leydig cells of the rat were highly responsive to hCG

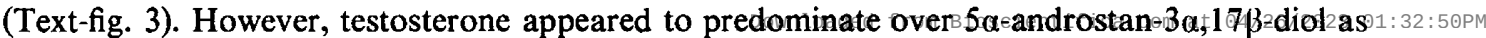


Table 2. The quantities of testosterone and $5 \alpha$-androstan$3 \alpha, 17 \beta$-diol produced by rat Leydig cells at different stages of development and after 8 days of hypophysectomy (in parentheses) under conditions of maximum stimulation with $\mathrm{hCG}$ in vitro

\begin{tabular}{ccc}
\hline Age (days) & Testosterone & 5a-Androstan-3a,17 $\beta$-diol \\
\hline 20 & 2 & 31 \\
28 & $7(6)$ & $166(13)$ \\
36 & 15 & 177 \\
38 & $36(30)$ & $109(68)$ \\
46 & 95 & 103 \\
58 & $187(96)$ & $63(35)$ \\
66 & 167 & 50 \\
\hline
\end{tabular}

Results are expressed as ng steroid $/ 10^{6} 3 \beta$-hydroxysteroid dehydrogenase-positive cells. All samples were subjected to celite chromatography in triplicate before assay.

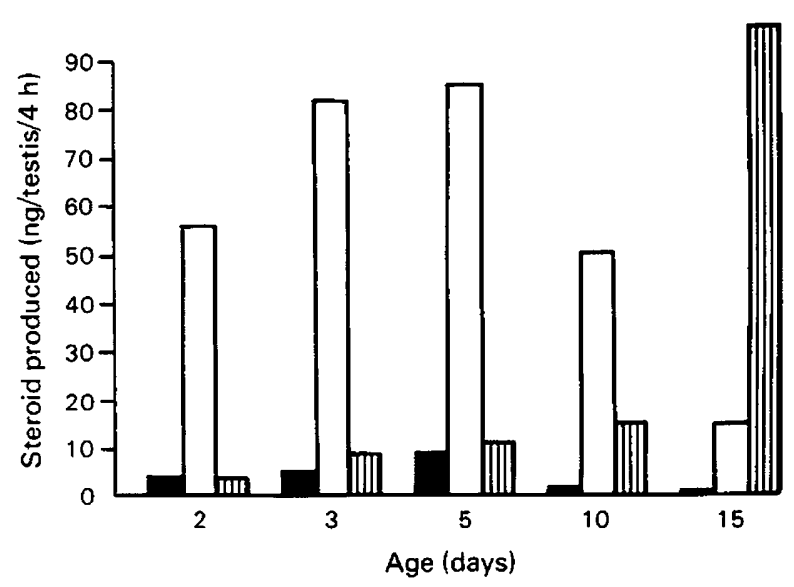

Text-fig. 3. In-vitro responsiveness of decapsulated rat testes to hCG $(10 \mathrm{ng} / \mathrm{ml})$ during the perinatal period. Testosterone was used as the response for basal (stippled columns) and stimulated (open columns) secretion. The quantity of $5 \alpha$-androstan-3 $\alpha, 17 \beta$-diol produced after stimulation is included for comparison (striped columns). Steroid measurements were performed after celite chromatography. All measurements were performed on pools of 5 or 6 testes/pool.

the major secretory product until 15 days of age when $5 \alpha$-androstan-3 $\alpha, 17 \beta$-diol began to be secreted in greater quantities.

\section{Changes in the $5 \alpha$-androstan-3a,17 $\beta$-diol:testosterone ratio throughout development}

Calculation of the $5 \alpha$-androstan-3 $3,17 \beta$-diol :testosterone ratio gives an arbitrary indication of the activity of the 5a-reductase in the Leydig cells in relation to the amounts of substrate produced. When the data from the above studies were pooled there was a gradual change in the ratio during development (Text-fig. 4). The production of $5 \alpha$-androstan-3 $\alpha, 17 \beta$-diol predominated over that of testosterone between 10 and 40 days of age but thereafter became

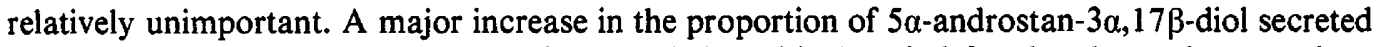
occurred between 10 and 15 days of age and the critical period for the changed proportions appeared to be Days 30-35. 


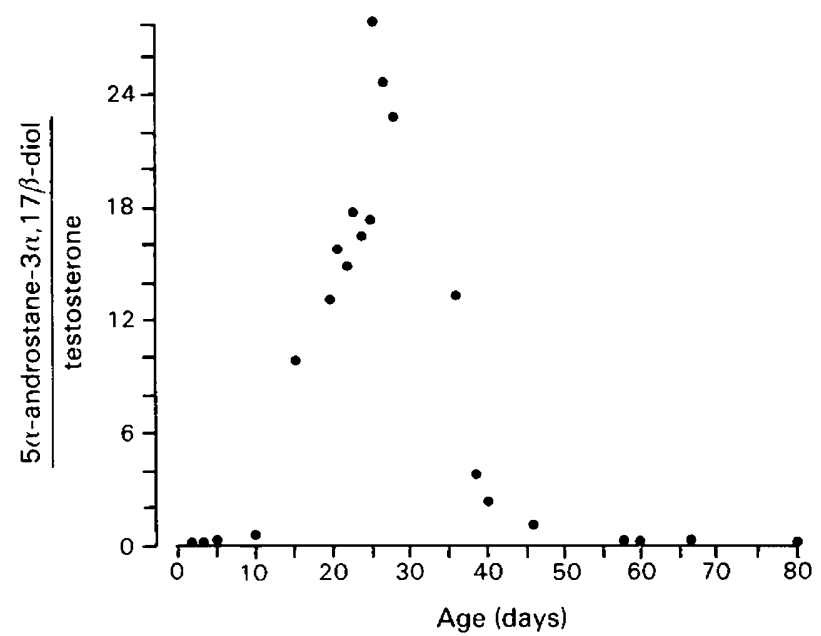

Text-fig. 4. Effects of age on the pattern of secretion of $5 \alpha$-androstane-3 $\alpha, 17 \beta$-diol and testosterone by rat Leydig cells after maximum stimulation with hCG.

\section{Discussion}

In confirmation of the previous study (Purvis et al., 1978b) the results indicate that the rat Leydig cell is highly responsive to $\mathrm{LH} / \mathrm{hCG}$ well before puberty. Maximum responsiveness (in terms of the maximum quantity of androgen secreted) is attained as early as 28-30 days. Although earlier studies suggested that responsiveness was subsequently attenuated, the present results do not confirm this, thus emphasizing the difficulty of defining steroidogenic responsiveness when the pattern of steroid products is also changing. Although the direct radioimmunoassay of $17 \beta$-hydroxyandrogens adequately reflects the steroid response of Leydig cells between 20 and 40 days of age (and the direct radioimmunoassay of testosterone thereafter) the secretory products must be separated chromatographically to compare accurately the amounts of steroids produced at widely different stages of development. Van der Molen, Roodnat \& Rommerts (1980) have shown that pregnenolone secretion by the Leydig cell is relatively constant after Day 30 of age, and this observation supports our suggestion that the steroidogenic response to hCG does not increase after this period.

The sensitivity of the Leydig cell (defined as $\mathrm{ED}_{50}$ ) undergoes a gradual decrease between 20 and 66 days of age, a fact which may explain the apparent major decrease in responsiveness over this period recorded in an earlier study (Purvis et al., 1978b) in which the dose of hCG used was $3 \mathrm{ng} / 2 \mathrm{ml}$, a concentration which gave a submaximal response in a 30-day-old rat. Thus, even small differences in sensitivity could be manifested in major differences in the quantity of steroid secreted by the Leydig cells when only one submaximal dose of hCG was used. The apparent inverse relationship between basal secretion and sensitivity of the dose-response curve (even more obvious after hypophysectomy, see below) implies that Leydig cells are primed and hypersensitive before endogenous trophic hormone secretion occurs. Subsequently, as the Leydig cell becomes more operational, its sensitivity is reduced. The reason for this change is not known but may be related to an alteration in phosphodiesterase activity (Purvis \& Hansson, 1978) or to precursor availability.

The critical period for the acquisition of $\mathrm{LH} / \mathrm{hCG}$ responsiveness and maximal steroidogenic capacity appears to be between 20 and 30 days of age. Previous work (Clausen, Purvis \& Hansson, 1979) has shown this to be a particularly important time in testicular development when a number of processes are initiated, including Sertolicell secretion (ABP secretion into the $1: 32: 50 \mathrm{PM}$ 
epididymis) and the first evidence of completion of the reduction division (appearance of haploid cells). This is also a period when the plasma levels of FSH (Payne et al., 1977), LH (Gupta, Rager, Zarzycki \& Eichner, 1975) and prolactin (Negro-Vilar, Krulich \& McCann, 1973; Døhler \& Wuttke, 1975) begin to be elevated.

What is the hormonal stimulus which confers increased responsiveness on the Leydig cell at this time? Although we have described an elevation in plasma FSH on Day 24 (Clausen et al., 1979), FSH does not appear to exert an influence on any of the characteristics of the dose-response curve of the rat Leydig cells (Purvis, Clausen \& Hansson, 1979). Prolactin may do so but this hormone acts on the steroidogenic apparatus in synergism with LH (Purvis, Clausen, Olsen, Haug \& Hansson, 1979) and does not exert any major effects alone. However, LH treatment of hypophysectomized rats stimulates, in a dose-dependent manner, the quantity of androgen produced per $10^{6}$ Leydig cells in response to hCG in vitro (Purvis, 1978). This is not surprising in view of the influence that this hormone has on the steroidogenic enzymes (Samuels \& Helmreich, 1956; Shikita \& Hall, 1967). This increase is inversely correlated with the changes in sensitivity of the dose-response curves and the changes in Leydig cell responsiveness occurring between Days 20 and 30 in the rat may therefore reflect a stimulation of pituitary LH secretion, probably in combination with similar changes in prolactin. The mechanisms underlying these changes in responsiveness are unknown. The numbers of receptors per $10^{6}$ Leydig cells do increase between 20 and 30 days of age, but only by a factor of 2 or 3 , and it is therefore more likely that the increased responsiveness constitutes a maturation of the steroidogenic apparatus induced by LH and prolactin.

Hypophysectomy at the 3 ages studied enhanced the sensitivity of the Leydig cells to hCG and decreased the amount of androgen secreted by each cell: after hypophysectomy for 8 days at 28,38 and 58 days the amount of $17 \beta$-hydroxyandrogen secreted was $13,67.6$ and $52 \%$ respectively of that obtained in intact animals at these ages. These differences in reaction to pituitary hormone withdrawal are intriguing but, as yet, not understood. One possibility is that they reflect differences in the sensitivity of the steroidogenic enzymes to pituitary hormones. Another, which is more likely, is that it is due to differences in the size of the precursor (e.g. cholesterol) pool and that such stores are depleted relatively more rapidly in the immature than in the adult animal. The LH receptor population of immature Leydig cells is relatively more resistant to the effects of hypophysectomy than that of adult rats (Purvis, Clausen, Ulvik \& Hansson, 1980), a finding which rules out the possibility that the age differences in susceptibility of the steroidogenic apparatus to hypophysectomy are due to differential effects on $\mathrm{L} H$ receptor levels.

Alterations in the $5 \alpha$-androstan-3 $\alpha, 17 \beta$-diol : testosterone ratio during development closely follow the changes observed in testicular $5 \alpha$-reductase observed by others (van der Molen, Grootegoed, de Greef-Bijleveld, Rommerts \& van der Vusse, 1975). It is likely that the activity of the $5 \alpha$-reductase is primarily responsible for the increasing predominance of $5 \alpha$-androstan$3 \alpha, 17 \beta$-diol as a secretory product between 10 and 40 days. It is apparent from these studies that the stimulation in the activity of the $5 \alpha$-reductase (between 10 and 15 days) does not occur at the time when there is the greater stimulation in Leydig cell responsiveness (20-30 days), suggesting possibly different hormonal mechanisms.

In the rat, there seem to be two generations of Leydig cells, a perinatal generation which is the remnants of the fetal Leydig cells and which gradually disappears from the testis after birth and until Day 10, and a second generation which appears between Days 10 and 20 and later constitutes the normal adult population (Niemi \& Ikonen, 1963; Lording \& de Kretser, 1972). The Leydig cells that primarily secrete testosterone before Day 15 could therefore represent the first generation while the cells that appear between Days 10 and 20 are a second generation which may develop with a $5 \alpha$-reductase capability already operational. The reduced ratio of secreted $5 \alpha$-androstan-3 $3,17 \beta$-diol :testosterone 8 days after hypophysectomy in immature rats reaffirms the generally accepted view that the activity of $5 \alpha+$ reductase $i$ is dependent, 2 at 2 least $t$ to 
some extent, on pituitary hormones (Nayfeh, Coffey, Hansson \& French, 1975). Moreover, the fact that the activity of this enzyme ceases so abruptly during normal development (between Days 35 and 40) suggests either that the hormonal stimulus is suddenly removed or that the enzyme has become inhibited (e.g. by androgen).

In conclusion, between birth and the attainment of adulthood there seem to be at least 4 major phases in the development of rat Leydig cells (in relation to their steroidogenic function): (1) the gradual phasing out during the perinatal period of a generation of Leydig cells which developed in utero and whose major secretory product was testosterone (birth-10 days); (2) the appearance of a new generation of Leyd:g cells which possess increasingly active $5 \alpha$-reductase and thus favours $5 \alpha$-androstan- $3 \alpha, 17 \beta$-diol as the major secretory product (10 days-adult); (3) a stimulation in steroidogenic potential of the second generation of Leydig cells with respect to their responsiveness to $\mathrm{LH}$ (20-30 days); and (4) a switching off of the $5 a$-reductase which results in testosterone once again becoming the predominant steroid secreted ( $30-40$ days). The last event, by encouraging the increased secretion of physiologically active androgen, is probably the major stimulus for the rat to enter puberty.

Supported by grants from the World Health Organization, the Norwegian Research Council for Science and the Humanities (NAVF), the Rockefeller Foundation and the Population Council (New York). We thank Anita Olsen for expert technical assistance and Liv Støttum for typing the manuscript.

\section{References}

Clausen, O.P.F., Purvis, K. \& Hansson, V. (1979) Endocrine correlates of meiosis in the male rat. Arch. Andrology 2, 59-66.

Coffey, J.C., French, F.S. \& Nayfeh, S.N. (1971) Metabolism of progesterone by rat testicular homogenates. IV. Further studies of testosterone formation in immature testis in vitro. Endocrinology 89, $865-872$.

Dohler, K.D. \& Wuttke, W. (1975) Changes with age in levels of serum gonadotropins, prolactin and gonadal steroids in prepubertal male and female rats. Endocrinology 97, 898-907.

Ficher, M. \& Steinberger, E. (1971) In-vitro progesterone metabolism by rat testicular tissue at different stages of development. Acta endocr., Copenh. 68, 285-292.

Gupta, D., Rager, K., Zarzycki, J. \& Eichner, M. (1975) Levels of luteinizing hormone, follicle-stimulating hormone, testosterone and dihydro-testosterone in the circulation of sexually maturing intact male rats and after orchidectomy and experimental bilateral cryptorchidism. J. Endocr. 66, 183-193.

Knorr, D.W., Vanha-Perttula, T. \& Lipsett, M.B. (1970) Structure and function of rat testis through pubescence. Endocrinology 86, 1298-1304.

Lording, D.W. \& de Kretser, D.M. (1972) Comparative ultrastructural and histochemical studies of the interstitial cells of the rat testis during fetal and postnatal development. J. Reprod. Fert. 29, 261269.

Matsumoto, K. \& Yamada, M. (1973) 5a-Reduction of testosterone in vitro by rat seminiferous tubules and whole testes at different stages of development. Endocrinology 93, 253-255.
Nayfeh, S.N., Barefoot, S.W., Jr \& Baggett, B. (1966) Metabolism of progesterone by rat testicular homogenates. II. Changes with age. Endocrinology 78, 1041-1048.

Nayfeh, S.N., Coffey, J.C., Hansson, V. \& French, F.S. (1975) Maturational changes in testicular steroidogenesis: hormonal regulation of $5 \alpha$-reductase. $J$. Steroid Biochem. 6, 329-335.

Negro-Vilar, A., Krulich, L. \& McCann, S.M. (1973) Changes in serum prolactin and gonadotropins during sexual development of the male rat. Endocrinology 93, 660-664.

Niemi, M. \& Ikonen, M. (1963) Histochemistry of the Leydig cells in the postnatal prepubertal testis of the rat. Endocrinology 72, 443-448.

Odell, W.D., Swerdloff, R.S., Bain, J., Wollesen, F. \& Grover, P.K. (1974) The effect of sexual maturation on testicular response to LH stimulation of testosterone secretion in the intact rat. Endocrinology 95, 1380-1384.

Payne, A.H., Kelch, R.P., Murono, E.P. \& Kerlan, J.T. (1977) Hypothalamic, pituitary and testicular function during sexual maturation of the male rat. $J$. Endocr. 72, 17-26.

Pahnke, V.G., Leidenberger, F.A. \& Kunzig, H.J. (1975) Correlation between HCG (LH)-binding capacity, Leydig cell number and secretory activity of rat testis throughout pubescence. Acta endocr., Copenh. 79, 610-618.

Purvis, K. (1978) Hormonal regulation of Leydig cell function. Ph.D. thesis, University of Oslo.

Purvis, K. \& Hansson, V. (1978) Leydig cell desensitisation by increased cAMP inactivation. Arch. Andrology 2, 89-91. 
Purvis, K., Clausen, O.P.F., Brandtzaeg, P. \& Hansson, V. (1978a) LH receptors and Leydig cell responsiveness to hCG in vitro. Arch. Andrology 1, 299310.

Purvis, K., Clausen, O.P.F. \& Hansson, V. (1978b) Age-related changes in responsiveness of rat Leydig cells to hCG. J. Reprod. Fert. 52, 379-386.

Purvis, K., Clausen, O.P.F. \& Hansson, V. (1979) LH contamination may explain FSH effects on rat Leydig cells. J. Reprod. Fert. 56, 657-665.

Purvis, K., Clausen, O.P.F., Olsen, A., Haug, E. \& Hansson, V. (1979) Prolactin and Leydig cell responsiveness to LH/hCG in the rat. Arch. Androl. 3, 219-230.

Purvis, K., Clausen, O.P.F., Ulvik, N.M. \& Hansson, V. (1980) Functional and morphological characteristics of rat Leydig cells: effects of prepubertal and postpubertal hypophysectomy. In Testicular Development, Structure and Function, pp. 211-220. Eds E. Steinberger \& A. Steinberger. Raven Press, New York.
Samuels, L.T. \& Helmreich, M.L. (1956) The influence of chorionic gonadotropin on the $3 \beta$-ol dehydrogenase activity of testes and adrenals. Endocrinology 58, 435-442.

Shikita, M. \& Hall, P.F. (1967) Action of human chorionic gonadotropin in vivo upon microsomal enzymes in testes of hypophysectomized rats. Biochim. biophys. Acta 141, 433-435.

van der Molen, H.J., Grootegoed, J.A., de GreefBijleveld, M.J., Rommerts, F.F.G. \& van der Vusse, G.J. (1975) Distribution of steroids, steroid production and steroid metabolizing enzymes in rat testis. In Hormonal Regulation of Spermatogenesis, pp. 3-23. Eds F. S. French, V. Hansson, E. M. Ritzén \& S. N. Nayfeh. Plenum Press, New York.

van der Molen, H.J., Roodnat, E.M. \& Rommerts, F.F.G. (1980) Effects of age on pregnenolone and testosterone production by rat testis Leydig cells in response to LH. In Testicular Development, Structure and Function. Eds E. Steinberger \& A. Steinberger. Raven Press, New York.

Received 19 November 1979 